\title{
Investigation of In Vitro Efficacy of Boric Acid on Pseudomonas aeruginosa Strains Isolated from Diabetic Foot Infections
}

\author{
Diyabetik Ayak Enfeksiyonlarından Izole Edilen Pseudomonas aeruginosa Suşları Üzerinde \\ Borik Asidin In Vitro Etkinliğinin Incelenmesi
}

\author{
(D) Yavuz PiRHAN ${ }^{1}$, (D) Mustafa CiHANGIROĞLU² \\ ${ }_{1}^{1}$ Amasya University Sabuncuoğlu Şerefeddin Training and Research Hospital, Department of General Surgery, Amasya, Turkey \\ 2Amasya University Sabuncuoğlu Şerefeddin Training and Research Hospital, Department of Infectious Diseases and Clinical Microbiology, \\ Amasya, Turkey
}

\section{Abstract}

Introduction: The aim of this study is to investigate the efficacy of boric acid as an antiseptic agent for use in wound care against Pseudomonas aeruginosa ( $P$. aeruginosa) strains isolated from diabetic foot infections.

Materials and Methods: A total of 25 P. aeruginosa strains isolated from diabetic foot infections were included in the study between January 2010 and June 2015. The susceptibility of these strains to various antibiotics was determined. Dilutions of various concentrations were prepared from boric acid to test these strains' growth at different concentrations. Our study was conducted in accordance with the Helsinki Declaration.

Results: At the end of the incubation period, growth was observed in all isolates to which $1.6 \mathrm{mg} / \mathrm{l}$ boric acid solution was exposed. No growth was observed in any of the 25 wells to which $25 \mathrm{mg} / \mathrm{l}, 50 \mathrm{mg} / \mathrm{l}$, and $100 \mathrm{mg} / \mathrm{l}$ boric acid solution was added. A significant difference was observed between the lowest concentration without reproduction $(25 \mathrm{mg} / \mathrm{l}$ boric acid) and other concentrations where reproduction was detected. The minimum inhibitory concentration of boric acid for $P$. aeruginosa was $25 \mathrm{mg} /$. High antibiotic resistance was noteworthy in $P$. aeruginosa strains, which reproduced at low boric acid concentrations.

Conclusion: Boric acid has an in vitro inhibitory effect on P. aeruginosa strains isolated from diabetic foot infections. Low-cost boric acid may be a suitable option for the local treatment of diabetic foot infections caused by $P$. aeruginosa.

Keywords: Antibiotic resistance, diabetic foot infection, P. aeruginosa, boric acid

\section{Öz}

Giriş: Bu çalışmada diyabetik ayak enfeksiyonlarından izole edilen Pseudomonas aeruginosa (P. aeruginosa) suşlarına karşı yara bakımında kullanılan bir antiseptik ajan olan borik asitin etkinliğinin belirlenmesi amaçlanmaktadır.

Gereç ve Yöntem: Çalışmaya Ocak 2010 - Haziran 2015 tarihleri arasında diyabetik ayak enfeksiyonlarından izole edilen toplam 25 adet $P$. aeruginosa suşu alındı. Bu suşların çeşitli antibiyotiklere duyarlııkları belirlendi. Borik asitten çeşitli konsantrasyonlarda dilüsyonlar hazırlanarak bu suşların farklı konsantrasyonlarda üremesi test edildi. Çalışmamız Helsinki Deklarasyonu uyarınca yapıldı.

Bulgular: İnkübasyon süresi sonunda 1,6 mg/l borik asit çözeltisinin maruz bırakıldığı tüm izolatlarda üreme gözlendi. $25 \mathrm{mg} / \mathrm{l}, 50 \mathrm{mg} / \mathrm{lve} 100 \mathrm{mg} / \mathrm{l}$ borik asit çözeltilerinin eklendiği 25 kuyucuğun hiçbirinde üreme gözlenmedi. Üremenin olmadığı en düşük konsantrasyon olan 25 mg/l borik asit konsantrasyonu ile üremenin tespit edildiği diğer konsantrasyonlar arasında anlamlı bir fark gözlenmiştir. Borik asitin P. aeruginosa için minimum

Cite this article as: Pirhan Y, Cihangiroğlu M. Investigation of In Vitro Efficacy of Boric Acid on Pseudomonas aeruginosa Strains Isolated from Diabetic Foot Infections. Mediterr J Infect Microb Antimicrob 2021;10:1. 
inhibitör konsantrasyonu 25 mg/l olarak bulundu. Düşük borik asit konsantrasyonlarında üreyen P. aeruginosa suşlarında yüksek antibiyotik direnci dikkat çekiciydi.

Sonuç: Borik asit, diyabetik ayak enfeksiyonlarından izole edilen $P$. aeruginosa suşlarına karşı in vitro etkinlik göstermektedir. Maliyeti düşük olan borik asitin P. aeruginosa'nın neden olduğu diyabetik ayak enfeksiyonlarında lokal tedavide uygun bir seçenek olabileceğine inanıyoruz.

Anaktar Kelimeler: Antibiyotik direnci, diyabetik ayak enfeksiyonu, P. aeruginosa, borik asit

\section{Introduction}

Foot infections are among the serious and frequent complications of diabetes ${ }^{[1]}$ and are a significant cause of morbidity and mortality. About one-fourth of all individuals with diabetes develop foot infections. These infections are a contributing cause of hospital admissions ${ }^{[2]}$. Diabetic foot infections are generally associated with a more prolonged hospital stay than the other complications of diabetes, and are a major cause of non-traumatic lower extremity amputations ${ }^{[3]}$. Infections in the diabetic foot cause prolongation of the disease and increase treatment costs $^{[4]}$. Despite some geographical differences, recent studies found a predominance of resistant Gramnegative bacteria in diabetic foot infections than staphylococci. In this regard, $P$. aeruginosa is a gram-negative pathogen commonly isolated in many diabetic foot wound studies ${ }^{[5,6]}$. The follow-up and treatment of diabetic foot infections require a multidisciplinary approach. Wound care is an integral part of treatment.

While boric acid has been used for centuries as a topical antiseptic agent to treat wound infections, the effectiveness of boric acid has been neglected. Its effectiveness has not been extensively investigated with the introduction of antibiotics for wound treatment ${ }^{[7]}$. Boric acid $\left(\mathrm{H}_{3} \mathrm{BO}_{3}\right)$ is a compound with a $\mathrm{pH}$ of approximately five and is found in trace amounts in the human body. Its molecular weight is $61.84 \mathrm{~g} / \mathrm{mol}$ and is moderately water soluble ${ }^{[8]}$. Boric acid is a compound with defined antioxidant, anti-inflammatory, anti-cancer, anticandidal, and antimicrobial properties. It is used as an antiseptic or buffering agent, and it is not absorbed from the skin's surface $^{[9]}$. For this reason, this study was designed using boric acid to treat diabetic foot wounds with $P$. aeruginosa infection.

\section{Materials and Methods}

Twenty-five $P$. aeruginosa strains isolated from diabetic foot wounds between January 2010 and June 2015 were included in the study. A single clinical example from each patient was included in the study. Identification of isolated strains was made using the VITEK 2 automated system (bioMérieux, France) after detecting $P$. aeruginosa's typical findings by conventional methods (typical aromatic odor, colony morphology, and oxidase test). Isolates antibiotic resistance status was determined by the VITEK 2 system and E-test (AB Biodisk, Sweden) method and evaluated according to Clinical and Laboratory Standards Institute criteria. Isolates were stored at $-70{ }^{\circ} \mathrm{C}$ in $150 \mathrm{mg} / \mathrm{l}$ glycerol agar. During the study, they were inoculated on eosin methylene blue (EMB) agar and incubated for 24 hours at $37{ }^{\circ} \mathrm{C}$. In this study, a $200 \mathrm{mg} / \mathrm{l}$ liquid solution was prepared using powder boric acid between $40{ }^{\circ} \mathrm{C}$ and $50{ }^{\circ} \mathrm{C}$ to form the boric acid concentrations. Following this first step, $100 \mu \mathrm{l}$ of this solution was added to the well of the microplate. Next, $100 \mu \mathrm{l}$ of McFarland 0.5 turbid bacterial solution was added to the well. Finally, $100 \mathrm{mg} / \mathrm{l}$ concentration of the boric acid solution was completed in the first well. The dilution was performed to achieve boric acid concentrations of $50 \mathrm{mg} / \mathrm{l}, 25 \mathrm{mg} / \mathrm{l}, 12.5 \mathrm{mg} / \mathrm{l}, 6 \mathrm{mg} / \mathrm{l}$, $3.2 \mathrm{mg} / \mathrm{l}$, and $1.6 \mathrm{mg} / \mathrm{l}$, and kept at $37^{\circ} \mathrm{C}$ for 12 hours. The $\mathrm{pH}$ of the wells varied between 6 and 6.5. For each isolate, a control inoculation was performed with sterile physiological saline. After incubation at $37^{\circ} \mathrm{C}$ for 12 hours, they were transferred onto EMB agar for bacterial growth determination. Comparing the isolates antibiotic susceptibility and their growth levels in different boric acid concentrations were conducted. For this study, ethics committee approval was received from the Noninvasive Clinical Research Ethics Committee of the University of Amasya (decision number: 2021/01, date: 07.01.2021).

\section{Statistical Analysis}

All analyses were conducted using the Statistical Package for the Social Sciences (SPSS) version 16.0 (SPSS, Chicago, IL, USA). The chi-square test was used. $P$ values of $<0.05$ were considered statistically significant.

\section{Results}

At the end of the incubation period, growth was observed in all the isolates exposed to $1.6 \mathrm{mg} / \mathrm{l}$ boric acid solution. Growth was observed in 22 of 25 wells exposed to $3.2 \mathrm{mg} / \mathrm{l}$ boric acid solution, 12 of 25 wells exposed to $6 \mathrm{mg} / \mathrm{l}$ boric acid solution, and five of 25 wells exposed to $12.5 \mathrm{mg} / \mathrm{l}$. There was no bacterial growth in any isolate exposed to a boric acid solution at concentrations of $25 \mathrm{mg} / \mathrm{l}$ or greater (Table 1, Figure 1). Growth was observed in all control groups. A significant difference was observed between $25 \mathrm{mg} / \mathrm{l}$ boric acid concentration, which is the lowest concentration where reproduction is absent, and other concentrations where reproduction was detected. Bacterial growth was not observed at concentrations of $25 \mathrm{mg} / \mathrm{l}, 50 \mathrm{mg} / \mathrm{l}$ and $100 \mathrm{mg} / \mathrm{l}$. In contrast, bacterial growth was observed at concentrations of $1.6 \mathrm{mg} / \mathrm{l}, 3.2 \mathrm{mg} / \mathrm{l}, 6 \mathrm{mg} / \mathrm{l}$, and $12.5 \mathrm{mg} / \mathrm{l}$ boric 
acid. The lowest minimum inhibitory concentration value for $P$. aeruginosa was $25 \mathrm{mg} / \mathrm{l}$ boric acid concentration. Antibiogram susceptibilities of $P$. aeruginosa isolates are presented in Table 2. Five isolates that can grow in $12.5 \mathrm{mg} / \mathrm{l}$ boric acid solution were resistant to cefepime, ceftazidime, ciprofloxacin, amikacin, and netilmicin. In addition, one of these isolates was resistant to all antibiotics. Our results suggest a linear correlation between the concentrations of boric acid and the resistance of $P$. aeruginosa to antibiotics. Therefore, as the concentrations of boric acid increase, the resistance of $P$. aeruginosa against antibiotics also increases.

\section{Discussion}

As emphasized by the International Diabetic Foot Working Group, diabetic foot management requires a multidisciplinary approach, including relieving pressure, ensuring skin perfusion, managing infection, controlling metabolism, and providing local wound care $^{[8]}$. Dressings play a key role in the continuity of wound care. Previous studies established the efficacy of wet wound care models, which led to the introduction of different wound care products (hydrogel, hydrocolloid dressing materials $)^{[9]}$. An ideal dressing material should prevent drying, absorb exudative secretions, allow gas exchange, and provide a barrier between the wound and contaminated environments ${ }^{[1]}$ Antiseptic agents, such as hydrogen peroxide, povidone-iodine, acetic acid, and others, have toxic properties. Therefore, their role in diabetic wound care is generally discouraged ${ }^{[10]}$. Removal of keratotic skin at wound margins and the facilitation of superficial epithelization are significant measures for wound care ${ }^{[8,10]}$. For this reason, we chose boric acid as it has little or no irritant effect

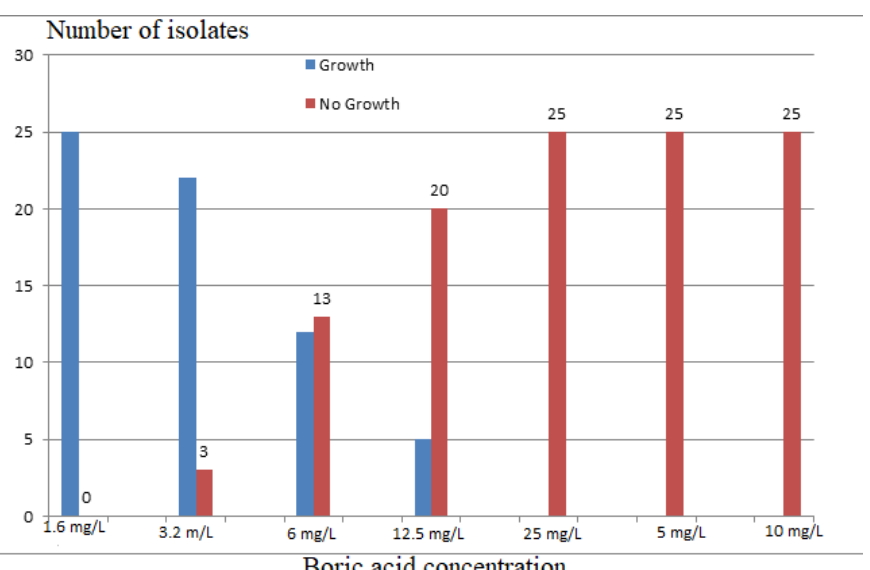

Figure 1. Relationship between boric acid concentrations and bacterial counts

\begin{tabular}{lll}
\hline \multicolumn{1}{l}{ Table 1. The total number of bacterial growth in different boric acid concentrations } \\
\hline Boric acid concentrations $(\mathbf{m g} / \mathbf{l})$ & Bacteria growth, $\mathbf{n} / \mathbf{N}(\%)$ & $\mathbf{p}$ value \\
\hline $1.6 \mathrm{mg} / \mathrm{l}$ & $25 / 25(100)$ & $\mathrm{p}=$ incalculable \\
\hline $3.2 \mathrm{mg} / \mathrm{l}$ & $22 / 25(88)$ & $\mathrm{p}=0.074$ \\
\hline $6 \mathrm{mg} / \mathrm{l}$ & $12 / 25(48)$ & $\mathrm{p}=0.000071$ \\
\hline $12.5 \mathrm{mg} / \mathrm{l}$ & $5 / 25(20)$ & $\mathrm{p}<0.0001$ \\
\hline $25 \mathrm{mg} / \mathrm{l}$ & $0 / 25(0)$ & $\mathrm{p}<0.0001$ \\
\hline $50 \mathrm{mg} / \mathrm{l}$ & $0 / 25(0)$ & $\mathrm{p}<0.0001$ \\
\hline $100 \mathrm{mg} / \mathrm{l}$ & $0 / 25(0)$ & $\mathrm{p}<0.0001$ \\
\hline
\end{tabular}

$\mathrm{n}$ : The number of $P$. aeruginosa isolates that reproduce after acid boric is applied.

$\mathrm{N}$ : The number of $P$. aeruginosa isolates.

Table 2. Antibiotic susceptibility of isolated $P$. aeruginosa strains $(\mathrm{n}=25)$

\begin{tabular}{|c|c|c|c|c|c|c|c|}
\hline Antibiotics & $S$ & & $I$ & & $\mathbf{R}$ & & CLSI limit values $^{[24]}$ \\
\hline & $\mathrm{n}$ & $\%$ & $n$ & $\%$ & $\mathrm{n}$ & $\%$ & \\
\hline Cefepime & 7 & 28 & 3 & 12 & 15 & 60 & $\leq 8 \neg \geq 32$ \\
\hline Amikacin & 15 & 60 & 3 & 12 & 7 & 28 & $\leq 16 \neg \geq 64$ \\
\hline Netilmicin & 16 & 64 & 4 & 12 & 5 & 20 & $\leq 8 \neg \geq 32$ \\
\hline Meropenem & 22 & 88 & 2 & 8 & 1 & 4 & $\leq 4 \neg \geq 16$ \\
\hline Ciprofloxacin & 16 & 64 & 3 & 12 & 6 & 24 & $\leq 1 \neg \geq 4$ \\
\hline Cefoperazone/sulbactam & 22 & 88 & 2 & 8 & 1 & 4 & $\leq 16 \neg \geq 64$ \\
\hline Piperacillin/tazobactam & 23 & 92 & 1 & 4 & 1 & 4 & $\leq 64 \backslash 4 \neg \geq 128 \backslash 4$ \\
\hline
\end{tabular}

S: Susceptible, I: Intermediate, R: Resistant 
on human skin. P. aeruginosa is more common in developing countries with warm climates, especially in Asia and Africa. Patients exposing their ulcers to water or moist environments also increase their risk for $P$. aeruginosa infection ${ }^{[11]}$. P. aeruginosa forms biofilms more readily in the diabetic wound environment, which leads to increased resistance to antimicrobial agents. This could help explain why diabetic wounds are typically slower to heal and more difficult to treat than non-diabetic wounds ${ }^{[12]}$. In addition, increased drug resistance makes infection treatment caused by this pathogen difficult ${ }^{[13]}$. Boric acid is an inorganic substance ingested in low amounts daily with food and drinks, and the majority is excreted via the urine within 24 hours. Boric acid absorption through the skin is negligible unless the skin's integrity has been disrupted. It is also applied locally for the treatment of vulva-vaginal candidiasis ${ }^{[14]}$. Boric acid is involved in many enzymatic processes, the stability of the cell membrane, the metabolism of vitamin D and steroids, and the development of mental functions. Studies have found that even 3 to 5 grams of boric acid taken orally may lead to toxic effects. On the other hand, it may also augment phagocytic functions and may exert anti-bacterial and anti-candidal effects ${ }^{[15,16]}$. In wound care, generally, a $2 \%$ concentration of boric acid is applied ${ }^{[17]}$. Kujath and Hügelschäffer ${ }^{[18]}$ were the first to state that boric acid at a $3 \%$ concentration was used against pseudomonal wound infection. They emphasized that such a dose can benefit treatment without any side effects. Also, Adarchenko et al. ${ }^{[19]}$ studied and analyzed boric acid. They concluded that it could be more effective against isolates of $P$. aeruginosa when compared with other agents. However, due to its toxicity, it may be hard to handle safely. According to the research conducted, boric acid's bactericidal effect has more than one target in the bacteria cell. $P$. aeruginosa develops resistance to antibiotics by using an intrinsic defense mechanism, changing its membrane structure against antibiotics, producing enzymes inactivating antibiotics, and draining antibiotic agents from bacterial cells via efflux pumps. Boric acid acts as a bactericidal against $P$. aeruginosa ${ }^{[20]}$. Boric acid can help in the local treatment of wounds caused by $P$. aeruginosa. Further, there is evidence that the appearance of the biofilms in infections, such as chronic wound infection, chronic otitis media, chronic rhinosinusitis, urinary tract infections caused by catheter use, and keratitis caused by contact lenses, is linked to $P$. aeruginosa ${ }^{[21]}$. Youn et al. ${ }^{[22]}$ found that a $4 \%$ boric acid concentration is a strong biofilm inhibitor. However, according to Youn et al. ${ }^{[22]}$, boric acid had to remain in the same environment with bacteria for a long time (24-72 hours) to be effective at a concentration of $4 \%$. Likewise, Saha et al. ${ }^{[17]}$ tested the boric acid on P. aeruginosa and observed the anti-biofilm property of boric acid. This led them to conclude that boric acid application could be used as an alternative treatment method against $P$. aeruginosa. Based on this, they applied a $2 \%$ concentration of boric acid for wound care. In a study conducted by Kumara et al. ${ }^{[23]}$, the researchers evaluated the effectiveness of ascorbic acid, acetic acid, and boric acid on several microorganisms. They reported that thirty minutes incubation of $0.5 \%, 1 \%$, and $2.5 \%$ concentrations of boric acid was effective for inhibition of ten $P$. aeruginosa isolates. Similarly, there was no growth in the twenty-five $P$. aeruginosa isolates in the present study after 12 hours of incubation at $25 \mathrm{mg} / \mathrm{l}$ and higher concentrations. This research is subject to a limitation. It was difficult to collect $P$. aeruginosa strains in diabetic wound infections. Therefore, we recommend that future researchers focus on collecting more isolates in their studies.

\section{Conclusion}

Boric acid showed in vitro efficacy against $P$. aeruginosa strains isolated from diabetic foot infections. We suggest that the minimum of $25 \mathrm{mg} / \mathrm{l}$ concentration of boric acid could be a good option in wound care treatment since it provides costeffective treatment for long-term care, reduces hospitalization periods, makes treatments at home possible, and enables local treatment rather than systemic treatment.

\section{Acknowledgment}

We would like to appreciate the contributions of the laboratory personnel and the translation support by Mr. Ali Duran.

\section{Ethics}

Ethics Committee Approval: Ethics committee approval was received from the Non-invasive Clinical Research Ethics Committee of the University of Amasya (decision number: 2021/01, date: 07.01.2021).

Informed Consent: Retrospective study.

Peer-review: Externally and internally peer-reviewed.

\section{Authorship Contributions}

Surgical and Medical Practices: Y.P., M.C., Concept: M.C., Design: Y.P., M.C., Data Collection or Processing: Y.P., M.C., Analysis or Interpretation: Y.P., M.C., Literature Search: Y.P., M.C., Writing: Y.P., M.C.

Conflict of Interest: No conflict of interest was declared by the authors.

Financial Disclosure: The authors declared that this study received no financial support.

\section{References}

1. Lipsky BA, Berendt AR, Cornia PB, Pile JC, Peters EJ, Armstrong DG, Deery HG, Embil JM, Joseph WS, Karchmer AW, Pinzur MS, Senneville E, Infectious Diseases Society of America. 2012 Infectious Diseases Society of America clinical practice guideline for the diagnosis and treatment of diabetic foot infections. Clin Infect Dis. 2012;54:e132-73. 
2. Brem H, Sheehan P, Rosenberg HJ, Schneider JS, Boulton AJ. Evidence-based protocol for diabetic foot ulcers. Plast Reconstr Surg. 2006;117:193S-209S; discussion 210S-1S.

3. Van Battum P, Schaper N, Prompers L, Apelqvist J, Jude E, Piaggesi A, Bakker K, Edmonds M, Holstein P, Jirkovska A, Mauricio D, Ragnarson Tennvall G, Reike H, Spraul M, Uccioli L, Urbancic V, van Acker K, van Baal J, Ferreira I, Huijberts M. Differences in minor amputation rate in diabetic foot disease throughout Europe are in part explained by differences in disease severity at presentation. Diabet med. 2011;28:199-205.

4. Prompers $L$, Huijberts $M$, Schaper $N$, Apelqvist J, Bakker $K$, Edmonds $M$, Holstein P, Jude E, Jirkovska A, Mauricio D, Piaggesi A, Reike $H$, Spraul M, Van Acker K, Van Baal S, Van Merode F, Uccioli L, Urbancic V, Ragnarson Tennvall G. Resource utilisation and costs associated with the treatment of diabetic foot ulcers. Prospective data from the Eurodiale Study. Diabetologia. 2008;51:1826-34.

5. Kosinski MA, Joseph WS. Update on the treatment of diabetic foot infections. Clin Podiatr Med Surg. 2007;24:383-96.

6. Ramakant P, Verma A, Misra R, Prasad K, Chand G, Mishra A, Agarwal G, Agarwal A, Mishra S. Changing microbiological profile of pathogenic bacteria in diabetic foot infections: time for a rethink on which empirical therapy to choose? Diabetologia. 2011;54:58-64.

7. Savini V, Catavitello C, Bianco A, Balbinot A, D'Antonio F, D'Antonio D. Azole resistant Candida glabrata vulvovaginitis treated with boric acid. Eur J Obstet Gynecol Reprod Biol. 2009;147:112.

8. Bakker K, Apelqvist J, Schaper NC, International Working Group on Diabetic Foot Editorial Board. Practical guidelines on the management and prevention of the diabetic foot 2011. Diabetes Metab Res Rev. 2012;28:22531.

9. Hilton J, Williams D, Beuker B, Miller D, Harding K. Wound dressings in diabetic foot disease. Clin Infect Dis. 2004;39:S100-3.

10. Brem $H$, Sheehan $P$, Boulton AJ. Protocol for treatment of diabetic foot ulcers. Am J Surg. 2004;187:S1-10.

11. Weintrob AC, Sexton DJ, Calderwood S, Baron EL. Clinical manifestations, diagnosis, and management of diabetic infections of the lower extremities. UpToDate. Waltham, MA. 2014. Available from: https://www.uptodate.com/ contents/clinical-manifestations-diagnosis-and-management-of-diabeticinfections-of-the-lower-extremities?topic Ref=1749\&tsource=see_link

12. Damir A. Why diabetic foot ulcers do not heal. J Int Med Sci Acad. 2011;24:205-6.
13. Lautenbach E, Weiner MG, Nachamkin I, Bilker WB, Sheridan A, Fishman NO. Imipenem Resistance Among Pseudomonas aeruginosa Isolates Risk Factors for Infection and Impact of Resistance on Clinical and Economic Outcomes. Infect Control Hosp Epidemiol. 2006;27:893-900.

14. US Department of Health and Human Services. Agency for Toxic Substances and Disease Registry: Toxicological profile for Lead (update) PB/99/166704. Atlanta: US Department of Health and Human Services. 1999.

15. De Seta F, Schmidt M, Vu B, Essmann M, Larsen B. Antifungal mechanisms supporting boric acid therapy of Candida vaginitis. J Antimicrob Chemother 2009;63:325-36.

16. Nielsen FH, Meacham SL. Growing evidence for human health benefits of boron. Evid. Based Complementary Altern. Med. 2011;16:169-80.

17. Saha N, Saarai A, Roy N, Kitano T, Saha P. Polymeric biomaterial based hydrogels for biomedical applications. J Biomater Nanobiotechnol. $2011 ; 2: 85-90$

18. Kujath $\mathrm{P}$, Hügelschäffer C. Pseudomonas aeruginosa: pathogenicity prevention and therapeutic approaches. Zentralbl Chir. 1987;112:558-63.

19. Adarchenko A, Krasil'nikov A, Sobeshchuk 0. Antiseptic sensitivity of clinical strains of Pseudomonas aeruginosa. Antibiot Khimioter. 1989;34:902-7.

20. Bruchmann $S$, Dötsch $A$, Nouri $B$, Chaberny $I F$, Häussler S. Quantitative contributions of target alteration and decreased drug accumulation to Pseudomonas aeruginosa fluoroquinolone resistance. Antimicrob Agents Chemother. 2013;57:1361-8.

21. Römling $U$, Balsalobre $C$. Biofilm infections, their resilience to therapy and innovative treatment strategies. J Int Med. 2012;272:541-61.

22. Youn CK, Jang SJ, Jo ER, Choi JA, Sim JH, Cho Sl. Comparative antibacterial activity of topical antiseptic eardrops against methicillin-resistant Staphylococcus aureus and quinolone-resistant Pseudomonas aeruginosa. Int J Pediatr Otorhinolaryngol. 2016;85:80-3.

23. Kumara D, Fernando $S$, Kottahachchi J, Dissanayake D, Athukorala G, Chandrasiri N, Damayanthi K, Hemarathne M, Pathirana A. Evaluation of bactericidal effect of three antiseptics on bacteria isolated from wounds. J Wound Care. 2015;24:5-10.

24. Dudley MN, Ambrose PG, Bhavnani SM, Craig WA, Ferraro MJ, Jones RN, Antimicrobial Susceptibility Testing Subcommittee of the Clinical and Laboratory Standards Institute. Background and rationale for revised Clinical and Laboratory Standards Institute interpretive criteria (breakpoints) for Enterobacteriaceae and Pseudomonas aeruginosa: I. Cephalosporins and aztreonam. Clin Infect Dis. 2013;56:1301-9. 